\title{
Social Analysis in the World Bank
}

\author{
Huw Evans, Eveline Herfkens, Ruth Jacoby, and Jan Piercy
}

1. The World Bank's mission has important environmental and social implications. These issues are of acute concern to our shareholders, as well as to civil society in both developed and developing countries. We believe that the World Bank now has moved significantly towards procedures and expertise to address environmental dimensions of its work. However, we are very concerned at the slow progress in establishing equivalent strengths in social analysis, which is essential to the Bank's objective of reducing poverty in an equitable and cost-effective manner.

2. Social issues have recently achieved a more prominent place on the international development cooperation agenda. We welcome the World Bank's renewed commitment to social development, including the Bank's active participation in the Social Summit (Copenhagen) and Women's Summit (Beijing). We are very appreciative of the President's own commitment to social issues, which he stated so clearly in his speech to the Annual Meetings, and in the recent Board discussion of evaluation results.

3. We acknowledge that much has been done in recent years to address specific social issues, such as resettlement, indigenous peoples, participation. However, this has been piecemeal. The Bank does not systematically ask the relevant questions on the social impact of its work, nor does it allocate adequate budget resources or deploy enough staff with the right skills. As a result, the Bank is facing increasing criticism for the adverse social impacts of its work, which it is ill-prepared to address.

4. With your new responsibilities for operations, we look to you for action on this important issue. Specifically, we recommend that you:

E. Herfkens $\cdot$ R. Jacoby $\cdot$ J. Piercy

Retired, The World Bank, NW Washington, DC, USA

(C) The Author(s) 2021 
(a) Issue an Operational Policy and Bank Procedure instructing the conduct of Social Assessments where appropriate for all operations (investment and adjustment): we note that OP/BP 10.04 (issued in April 1994) indicates that an OP/BP 10.06 on Sociological Criteria in investment operations is due to be issued, but over a year and a half later, this still has not occurred;

(b) Consider consolidating the Bank's social analysis expertise in a single focal point instead of spreading it between two central vice-presidencies;

(c) Meet the commitment to expand the social sector skill base, by establishing a cadre of social scientists in each region to carry out social analysis in country activities.

5. We also hope that you will promote more systematic social analysis in Economic and Sector Work.

Huw Evans trained as an economist and served for many years with the UK Treasury. He represented the United Kingdom on the World Bank Board between 1994-1997.

Eveline Herfkens. Prior to representing the Netherlands group on the World Bank Board between 1990-1996, Eveline Herfkens had served as a member of the House of Commons of the Dutch Parliament from 1981-1990.

Ruth Jacoby joined the World Bank Board in 1994 and served as the Chair of the Committee on Development Effectiveness (CODE).

Jan Piercy was appointed to the World Bank Board by US President Clinton in 1994. Prior to joining the World Bank, she had been Senior Vice President of Shorebank Corporation in Chicago, a bank holding company designed to promote economic development in disinvested urban and rural areas.

Open Access This chapter is licensed under the terms of the Creative Commons Attribution 4.0 International License (http://creativecommons.org/licenses/by/4.0/), which permits use, sharing, adaptation, distribution and reproduction in any medium or format, as long as you give appropriate credit to the original author(s) and the source, provide a link to the Creative Commons license and indicate if changes were made.

The images or other third party material in this chapter are included in the chapter's Creative Commons license, unless indicated otherwise in a credit line to the material. If material is not included in the chapter's Creative Commons license and your intended use is not permitted by statutory regulation or exceeds the permitted use, you will need to obtain permission directly from the copyright holder.

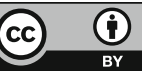

